\title{
The Control of Experimental Escherichia coli Diarrhoea in Calves by Means of Bacteriophages
}

\author{
By H. WILLIAMS SMITH, * MICHAEL B. HUGGINS AND \\ KATHLEEN M. SHAW \\ Institute for Animal Disease Research, Houghton Laboratory, Houghton, Huntingdon, \\ Cambridgeshire PE17 2DA, UK
}

(Received 18 September 1986; revised 12 December 1986)

\begin{abstract}
Seven phages highly active in vitro and in vivo against one or other of seven bovine enteropathogenic strains of Escherichia coli belonging to six different serotypes were isolated from sewage. Severe experimentally induced $E$. coli diarrhoea in calves could be cured by a single dose of $10^{5}$ phage organisms. It could be prevented by doses as low as $10^{2}$, by spraying the litter in the calf rooms with aqueous phage suspensions or simply by keeping the calves in uncleaned rooms previously occupied by calves whose $E$. coli infections had been treated with phage. Microbiological examinations of calves used in these experiments revealed that the phage organisms multiplied rapidly and profusely after gaining entry to the $E$. coli-infected small intestine, quickly reducing the $E$. coli to numbers that were virtually harmless. The only phageresistant $E$. coli that emerged in the studies on calves infected with one or other of the seven $E$. coli strains were $\mathrm{K}^{-}$. These organisms were much less virulent than the $\mathrm{K}^{+}$organisms from which they were derived and did not present a serious problem in calves given adequate amounts of colostrum. Infections produced by oral inoculation of a mixture of six strains of the $E$. coli could be controlled by administration of a pool of the six phages that were active against them but, in general, the control was less complete than that observed in the single-strain infections. $\mathrm{K}^{+}$phage-resistant bacteria emerged in some of the calves used in these mixed infections and they were as virulent as their parent organisms; evidence from in vitro studies suggested that they might have arisen by genetic transfer between organisms of the different infecting strains. Infections produced by these $\mathrm{K}^{+}$mutants and their parents could be controlled by the use of mutant phages derived from phages that were active on their parents. During the experiments with mixed $E$. coli infection, an extraneous phage active against one of the six $E$. coli strains suddenly appeared in calves kept in the same rooms. Microbiological examinations revealed that this phage was effectively controlling the multiplication of organisms of that particular strain of $E$. coli in the small intestines of the calves.
\end{abstract}

\section{INTRODUCTION}

It is generally believed that phages are of little value in controlling bacterial infections in man and domestic animals; the main reasons for their apparent failure are thought to be low activity in vivo compared with that in vitro and the rapid emergence of phage-resistant bacterial mutants during treatment. Recently, a generalized and a cerebral infection of mice with an $018: \mathrm{K} 1: \mathrm{H} 7$ Escherichia coli strain was studied to test the validity of this view (Smith \& Huggins, 1982). Contrary to expectations, an anti-K 1 phage proved more effective in controlling these infections than most antibiotics with which it was compared; this phage was highly active in vivo and the only phage-resistant bacterial mutants that emerged during treatment were $\mathrm{Kl}^{-}$and they were of low virulence. The investigation was extended to study the treatment of $E$. coli infections in an entirely different environment, the alimentary tract (Smith \& Huggins, 1983). Calves, piglets and lambs experimentally infected with enteropathogenic $E$. coli were used for this purpose, models 
possessing the important property of closely resembling the natural disease that occurs in these animals. Again success was obtained. Because this investigation revealed that phages possessed unique properties of potential value in the prophylaxis of bacterial enteric disease we decided to study them mainly as prophylactic rather than as curative agents in our calf $E$. coli diarrhoea model; the results are reported in this paper. A few calves, though, were given phages when they were already suffering from experimental $E$. coli diarrhoea, principally to obtain information on the in vivo virulence of phages.

All the phages found in our earlier work to have therapeutic potential had a very narrow spectrum of anti-bacterial activity, maximum activity only being directed against bacterial strains of the same serotype. Phages were now sought whose attack points were structures, such as the 99 antigen, which are widely distributed amongst enteropathogenic strains. Realizing that such a phage might not be found, as indeed it was not, the search was planned with the additional objective of obtaining a pool of narrow-spectrum phages which might act as a substitute. With considerable difficulty and over a period of several years of search, a pool of phages was eventually obtained which was therapeutically active against representative strains of six E. coli serotypes, probably the majority of those reported to be enteropathogenic for calves and lambs. As and when they were obtained, members of this pool were used in a series of experiments that ran concurrently with the phage search, experiments specifically designed to throw light on the potential value of phages in general for controlling natural bacterial enteric infections. All the members were used in at least one of several different types of experiment because it was felt that this would yield more information than would the use of only one phage in all experiments. Finally, the pool of phages was used in attempts to control infections produced by a mixture of the six $E$. coli strains.

\section{METHODS}

The procedures described below were standard for all experiments; any modification is referred to in the text when it occurs.

Bacterial strains. The six enteropathogenic E. coli strains used in most of the phage therapy studies were B41 (O101 : K30), B44 (O9 : K30), B79 (O101 : K32), B85 (O9 : K35), B1 17 (O8 : K85) and S48 (O101:K28); strain S13, of the same serotype as B117, was used in one experiment. All seven had been isolated from outbreaks of disease in calves (B) or lambs (S). Strain S48 had been received from Mr W. J. Soyka of the Central Veterinary Laboratory, Ministry of Agriculture, Fisheries and Food, Weybridge, Surrey, UK; the remaining six were described initially by Smith \& Halls (1967a). All seven strains were non-motile and produced the 99 antigen and heat-stable (ST) enterotoxin; all except $E$. coli B117 and S13 produced the F41 antigen. The strains that were antibiotic-sensitive, B44, B85 and S48, were used as spontaneous mutants resistant to nalidixic acid to facilitate their enumeration in the alimentary tract. To differentiate the six strains from each other in mixed infection experiments, antibioticresistant plasmids were inserted into some and spontaneous nalidixic acid or ampicillin resistant mutants were isolated from others. All strains altered in this manner were compared in mixed infection experiments with their parents to confirm that no obvious alteration in their ability to colonize the small intestine had occurred as a consequence of their genetic alteration. In oral challenge experiments, a spontaneous mutant of a nonenteropathogenic $E$. coli strain, P713, resistant to rifampicin and a lactobacillus culture, AHT1, were always given in the inoculum to simulate, to some extent, natural infection; the presence of P713 also aided assessment of the behaviour of the enteropathogenic strains in the alimentary tract. The lactobacillus, AHTl, isolated from the faeces of a healthy pig was not identified to species level.

Culture media and cultural conditions. Broth cultures consisted of organisms grown in $10 \mathrm{ml}$ nutrient broth, Oxoid no. 2 (CM67), in a shaking water bath (approximately 100 r.p.m.). The MacConkey's agar employed was Oxoid (CM7). The nutrient agar was Difco tryptose agar (B64) to which $\mathrm{CaCl}_{2}(0.02 \%)$ had been added because batches of nutrient agar had been found (Smith, 1948) that did not contain sufficient for staphylococcal phage activity. Towards the end of the work $\mathrm{CaCl}_{2}(0.03 \%)$ was also added to the nutrient broth used in phage searches because an extraneous phage, $S 48 / 2$, was isolated from the faeces of several of our experimental calves on the nutrient agar, a phage that could only be propagated in the nutrient broth if $\mathrm{CaCl}_{2}$ was added to it. The lactobacillus was grown on Rogosa's agar (Oxoid) for $48 \mathrm{~h}$ in an atmosphere of $\mathrm{H}_{2}$ containing $5 \%(\mathrm{v} / \mathrm{v}) \mathrm{CO}_{2}$. All other culture media were incubated aerobically at $37^{\circ} \mathrm{C}$ for $24 \mathrm{~h}$.

Phage search. This was based on the methods of Smith \& Huggins (1982). Phages active on the enteropathogenic strains were found only occasionally. None had a range of activity extending beyond strains possessing the same $K$ antigen. All were submitted to in vitro virulence tests and those of low virulence discarded. A mixture of equal numbers of all the undiscarded phages that were active on the same strain were given orally to a calf suffering from 
diarrhoea produced by the oral inoculation of that strain. A phage isolate obtained from the faeces of this calf $24 \mathrm{~h}$ later was purified, propagated and retained for use in the phage therapeutic studies. All the phages that were retained apparently did not establish lysogenic relationships with susceptible bacteria. They were designated by the number of the $E$. coli strain on which they were isolated followed by a number to differentiate them from other isolates made on the same $E$. coli strain.

In vitro phage virulence tests. These were performed by the method of Smith \& Huggins (1983). Because the activity of some phages is greatly influenced by temperature (accompanying paper: Smith et al., 1987), the tests were done in parallel at $37^{\circ} \mathrm{C}$ and $40^{\circ} \mathrm{C}$, the two temperatures encompassing the range of rectal temperatures observed in our healthy and infected calves.

Isolation of phage mutants active on hitherto phage-resistant E. coli strains. Attempts to isolate phage mutants that were active against a phage-resistant $E$. coli strain were made by inoculating broth in $500 \mathrm{ml}$ amounts with $10 \mathrm{ml}$ of a broth culture of the resistant $E$. coli strain and $20 \mathrm{ml}$ of an undiluted phage preparation. After incubation for $24 \mathrm{~h}, 20 \mathrm{ml}$ was removed, heat-treated and added to a fresh $500 \mathrm{ml}$ sample of broth inoculated with the resistant $E$. coli culture. This procedure was repeated 10 times. At the end of each passage a few drops of the heated material was inoculated onto a plate of nutrient agar spread with a lawn of the broth culture. After incubation the lawn was examined for phage plaques. Any that were present were purified and propagated and their in vitro virulence for the hitherto resistant strain determined.

Experimental animals. Calves were surplus males from Channel Island herds, aged 6-12 h when put under experiment; it is difficult to produce $E$. coli diarrhoea in calves more than $24 \mathrm{~h}$ old (Smith \& Halls, $1967 a$ ). It was never possible to get groups of calves at the same time so individual calves were used as and when they became available. Their colostrum status was confirmed by the zinc sulphate test (Aschaffenburg, 1949) and those that had not obtained colostrum were given 1.51 of cow's colostrum that had been stored at $-20^{\circ} \mathrm{C}$. Any to be used colostrum-deprived (stated as such in the text) were given $100 \mathrm{ml}$ of pooled normal pig serum subcutaneously to help prevent them developing systemic infections with extraneous organisms. All calves, depending on size, were given $1-1.51$ of sterilized cow's milk twice daily by stomach tube.

Inoculation with E. coli and phage and subsequent examination of experimental animals. Calves were given orally $10^{9}$ viable organisms of an enteropathogenic $E$. coli strain together with $10^{10}$ viable organisms of the nonpathogenic $E$. coli P713 strain and $10^{10}$ viable organisms of the lactobacillus strain AHT1; mixtures of enteropathogenic strains were given in equal numbers, the total dose being $10^{9}$ viable organisms. Phages were given per os in doses of $10^{5}$ viable organisms. In some experiments, though, they were sprayed as aqueous suspensions on the litter of calf rooms by means of a watering can. The clinical condition of the calves was assessed several times daily and the $E$. coli and phage content of their faeces determined twice daily. Experiments were terminated when the calves were $4 \mathrm{~d}$ old provided they were then normal. Attempts were made to classify diarrhoea into severe when it was copious and watery and accompanied by clinical signs of dehydration, moderate when it was copious and watery in the absence of other clinical signs and mild when it was liquid in character but relatively small in amount. Calves near to death or at other pre-determined times were killed by parenteral administration of sodium phenobarbitone. The concentrations of $E$. coli and phage in the contents of their abomasum, small intestine, colon and rectum, collected in cooled nutrient broth, were determined by a modification of the method of Miles \& Misra (1938); only freshly dead calves were submitted to microbiological examination because of the rapid increase in the numbers of bacteria that occurs in the small intestine after death (Smith \& Jones, 1963). The small intestine was divided into seven equal parts for this purpose to determine the degree of the $E$. coli and phage multiplication that had occurred throughout the organ.

Counts of $E$. coli were performed on plain MacConkey's agar (for the total $E$. coli count) and on MacConkey's agar containing such antibiotics as were necessary to distinguish all the inoculated $E$. coli strains from each other. Colonies of $\mathrm{K}^{-}$(phage-resistant) mutants of the enteropathogenic $E$. coli could easily be differentiated visually from their $\mathrm{K}^{+}$parent strains; when present they were always recorded separately from the $\mathrm{K}^{+}$organisms. The numbers of phage organisms were counted on well-dried plates of nutrient agar spread with lawns of broth cultures of susceptible bacteria diluted 10 times. Samples to be assayed for phages were first held at $58^{\circ} \mathrm{C}$ for $30 \mathrm{~min}$, a procedure that did not significantly reduce their potency.

\section{RESULTS}

\section{In vitro virulence of the phages used in the therapeutic studies}

The numbers of organisms of the phages required to lyse cultures of the $E$. coli strains against which they were used in the therapeutic studies are shown in Table 1; the results for an extraneous phage, $\mathrm{S} 48 / 2$, isolated from some of the calves used in those studies are also given. Phage B44/4, in addition to being active on $E$. coli B44, was slightly active on $E$. coli B41; these two $E$. coli strains possessed the same $\mathrm{K}$ antigen, K30. Phage B117/1 was more active on $E$. coli 
Table 1. In vitro virulence of the phages used in the therapeutic studies

Ten $\mathrm{ml}$ amounts of nutrient broth were inoculated with $10^{8}$ viable $E$. coli organisms and three-fold falling numbers of phage organisms and incubated for $5 \mathrm{~h}$ at $37^{\circ} \mathrm{C}$ or $40{ }^{\circ} \mathrm{C} ; 0.03 \% \mathrm{CaCl}_{2}$ was added to the broth used in the tests with phage $\mathrm{S} 48 / 2$ because this phage needed it for lysis. The smallest number of phage organisms required to lyse the $E$. coli culture was recorded as the minimum lethal dose (MLD).

\begin{tabular}{llcc}
\multicolumn{1}{c}{ E. coli strain } & \multicolumn{2}{c}{ MLD } \\
B41/1 & B41 (O101:K30) & $57^{\circ} \mathrm{C}$ & $40^{\circ} \mathrm{C}$ \\
B44/4 & B44 (O9:K30) & $10^{3}$ & $3 \times 10^{4}$ \\
B44/4 & B41 (O101:K30) & $10^{7}$ & $10^{5}$ \\
B79/2 & B79 (O101:K32) & $10^{3}$ & $3 \times 10^{7}$ \\
B85/1 & B85 (O9:K35) & $5 \times 10^{3}$ & $5 \times 10^{6}$ \\
B85/2 & B85 (O9:K35) & $5 \times 10^{3}$ & $5 \times 10^{6}$ \\
B85/3, 4, 5, 6, and 7 & B85 (O9:K35) & $6 \times 10^{6}-6 \times 10^{7}$ & $8 \times 10^{6}-2 \times 10^{8}$ \\
B117/1 & B117(O8:K85) & 2 & 2 \\
B117/1 & S13(O8:K85) & $2 \times 10^{7}$ & $2 \times 10^{8}$ \\
S13/2 & S13(O8:K85) & $2 \times 10^{5}$ & $5 \times 10^{5}$ \\
S13/2 & B117(O8:K85) & $2 \times 10^{4}$ & $5 \times 10^{4}$ \\
S48/1 & S48 (O101:K28) & 20 & $2 \times 10^{4}$ \\
S48/2 & S48 (O101:K28) & $10^{2}$ & $10^{2}$
\end{tabular}

B117 than on the other $\mathrm{O} 8: \mathrm{K} 85$ strain, S13. Phage S13/2, which had actually been isolated on $E$. coli S13, was also more active on B117 than on that strain. Most of the phages were more active at $37^{\circ} \mathrm{C}$ than at $40^{\circ} \mathrm{C}$. In the therapeutic studies the rectal temperatures of 21 infected control calves taken on 35 occasions and of 33 phage-treated calves taken on 50 occasions were all between these two values. Those for the control calves, median followed by range in parenthesis, were $38.8^{\circ} \mathrm{C}\left(37.1-39.5^{\circ} \mathrm{C}\right)$ and those for the treated calves were $38.5^{\circ} \mathrm{C}\left(37.0-39.4{ }^{\circ} \mathrm{C}\right)$.

\section{Important features of the disease produced by the E. coli strains}

The clinical and bacteriological observations made on the control calves used in the therapeutic studies are, for convenience and clarity, collected together and summarized in Tables 2 and 3. In general, all the strains produced severe diarrhoea within 12-24 h of inoculation. Calves so affected looked depressed and lethargic and clinical signs of dehydration soon became apparent. The dehydration usually progressed rapidly and terminated in collapse and death. The disease was, perhaps, most serious in calves given $E$. coli B79 or B85, slightly less serious in those given $E$. coli $\mathrm{B} 44$ or $\mathrm{S} 48$ and least serious in those given $E$. coli B117. This impression was reflected in the results of the bacteriological examinations of the calves when near to death (Table 3), highest counts in the anterior small intestine (the region of the intestine most susceptible to enterotoxin: Smith \& Halls, 1967 b) being found in the calves given $E$. coli B79 or B85. Although the calves had been given ten times more of the non-pathogenic $E$. coli P713 than of the enteropathogenic strains, the numbers of P713 in their small intestines was about $10^{5}$ times lower than those of the enteropathogenic strains. The high rectal counts (faeces) were a feature of the twice-daily counts made on the faeces of the calves after the onset of diarrhoea. These counts were usually in the region of $\left(\log _{10} g^{-1}\right) 9 \cdot 0-9 \cdot 5$. Phages acting on the infecting $E$. coli strains were not found in the faeces of any of the calves.

\section{Treatment of $E$. coli diarrhoea with a low dose of phage}

Seven calves inoculated with $E$. coli $\mathrm{B} 41$ were given $10^{5}$ viable organisms of phage $\mathrm{B} 41 / 1$ at the onset of diarrhoea. All recovered, the diarrhoea persisting for approximately $12 \mathrm{~h}$ (two calves), $15 \mathrm{~h}$ (three calves) or $20 \mathrm{~h}$ (two calves). High phage B41/1 counts, $\left(\log _{10} \mathrm{~g}^{-1}\right) 9 \cdot 0-10 \cdot 0$, were found in the faeces of the calves during the first $24 \mathrm{~h}$ after treatment. During this period the corresponding figures for the $E$. coli B41 counts were usually $7 \cdot 5-8 \cdot 7$. The counts of both phage and $E$. coli $\mathrm{B} 41$ then declined greatly. $\mathrm{K}^{-}$phage B41/1-resistant mutants of $E$. coli $\mathrm{B} 41$ appeared 
Table 2. Effect of giving different E. coli strains to calves

The calves were inoculated with $10^{9}$ viable organisms of the enteropathogenic strains together with $10^{10}$ viable organisms of the non-pathogenic $E$. coli $\mathrm{P} 713$ and $10^{10}$ viable organisms of the lactobacillus strain AHTl.

\begin{tabular}{|c|c|c|c|c|c|c|}
\hline Strain & $\begin{array}{l}\text { No. of } \\
\text { calves }\end{array}$ & $\begin{array}{l}\text { No. that } \\
\text { developed } \\
\text { diarrhoea }\end{array}$ & $\begin{array}{l}\text { Approx. time between } \\
\text { inoculation and } \\
\text { diarrhoea onset (h)* }\end{array}$ & $\begin{array}{c}\text { Approx. } \\
\text { duration of } \\
\text { diarrhoea }(h)^{*}\end{array}$ & $\begin{array}{l}\text { No. that } \\
\text { died }\end{array}$ & $\begin{array}{l}\text { Approx. survival } \\
\text { time of those } \\
\text { that died }(\mathrm{h})^{*}\end{array}$ \\
\hline B41 & 11 & 11 & $\begin{array}{l}12(2), 15,18(2), \\
20(2), 24(2), 30,36\end{array}$ & $\begin{array}{l}\text { Until death (10), } \\
24\end{array}$ & 10 & $\begin{array}{l}25(4), 30(4), \\
65,85\end{array}$ \\
\hline B44 & 14 & 13 & $\begin{array}{l}12(5), 15(3) \\
18(2), 24,30,46\end{array}$ & $\begin{array}{l}\text { Until death (11), } \\
36(2)\end{array}$ & 11 & $\begin{array}{c}25(2), 35(3) \\
50(3), 90(3)\end{array}$ \\
\hline B79 & 6 & 6 & $12(4), 15(2)$ & Until death (6) & 6 & $25(3), 35(3)$ \\
\hline B85 & 6 & 6 & $12,15(3), 18(2)$ & Until death (6) & 6 & $25(3), 40(2), 60$ \\
\hline B117 & 8 & 8 & $\begin{array}{l}12(2), 15(4) \\
20,30\end{array}$ & $\begin{array}{l}\text { Until death (4), } \\
35(2), 45,56\end{array}$ & 4 & $35,40,45(2)$ \\
\hline S48 & 6 & 6 & $15(4), 18,20$ & $\begin{array}{l}\text { Until death (5), } \\
40\end{array}$ & 5 & $\begin{array}{l}35,40,45 \\
60,85\end{array}$ \\
\hline S13 & 10 & 9 & $\begin{array}{l}12(2), 15(3) \\
18(2), 20(2)\end{array}$ & $\begin{array}{l}\text { Until death (7), } \\
70,80\end{array}$ & 7 & $\begin{array}{c}20,45(4) \\
65,90\end{array}$ \\
\hline
\end{tabular}

* The number of calves when this was $>1$ is given in parentheses.

Table 3. Median of the counts on the contents of the alimentary tract of calves near death after being given different strains of $E$. coli

The numbers of the enteropathogenic $E$. coli, non-pathogenic $E$. coli $\mathrm{P} 713$ and lactobacilli given were as for Table 2. The small intestine was divided into seven equal parts for counting; part 1 was next to the abomasum and part 7 next to the colon. The results quoted for $E$. coli P713 were obtained from the counts on the calves given the enteropathogenic strains.

\begin{tabular}{|c|c|c|c|c|c|c|c|c|c|c|c|}
\hline \multirow[b]{3}{*}{ Strain } & \multirow{3}{*}{$\begin{array}{l}\text { No. of } \\
\text { calves }\end{array}$} & \multicolumn{10}{|c|}{ No. of organisms $\left.\left(\log _{10}[\text { no. (g contents) })^{-1}\right]\right)$ in } \\
\hline & & \multirow[b]{2}{*}{ Abomasum } & \multicolumn{7}{|c|}{ Small intestine part: } & \multirow[b]{2}{*}{ Colon } & \multirow[b]{2}{*}{ Rectum } \\
\hline & & & 1 & 2 & 3 & 4 & 5 & 6 & 7 & & \\
\hline B41 & 10 & $4 \cdot 2$ & $5 \cdot 5$ & $5 \cdot 6$ & $8 \cdot 6$ & $9 \cdot 0$ & $9 \cdot 5$ & $9 \cdot 5$ & $9 \cdot 3$ & $9 \cdot 5$ & $9 \cdot 3$ \\
\hline B44 & 10 & 3.5 & $5 \cdot 4$ & $7 \cdot 8$ & $9 \cdot 2$ & $9 \cdot 5$ & $9 \cdot 5$ & $9 \cdot 8$ & 9.8 & $9 \cdot 4$ & $9 \cdot 6$ \\
\hline B79 & 6 & $6 \cdot 3$ & $7 \cdot 2$ & $8 \cdot 8$ & 9.8 & 9.6 & 9.6 & 9.4 & 9.7 & $9 \cdot 6$ & 9.5 \\
\hline B85 & 6 & 5.4 & $8 \cdot 6$ & 9.2 & 9.4 & 9.4 & 9.2 & $9 \cdot 4$ & $9 \cdot 3$ & 9.2 & 9.4 \\
\hline B 117 & 4 & 5.4 & $5 \cdot 6$ & 6.4 & 8.0 & 8.0 & $9 \cdot 0$ & 9.4 & 9.4 & $9 \cdot 3$ & $9 \cdot 4$ \\
\hline S48 & 5 & 3.4 & 4.9 & 7.9 & $9 \cdot 3$ & 9.3 & 9.5 & 9.7 & 9.5 & $9 \cdot 3$ & 9.8 \\
\hline $\mathrm{S} 13$ & 7 & 3.3 & 4.7 & 7.0 & 7.5 & $9 \cdot 4$ & 9.5 & 9.6 & 9.6 & 9.6 & 9.5 \\
\hline P713 & 48 & 3.9 & 4.8 & 4.9 & 4.6 & $4 \cdot 5$ & $4 \cdot 5$ & 4.4 & 4.5 & $5 \cdot 3$ & 5.5 \\
\hline
\end{tabular}

in the faeces of some of the calves in small numbers at about $40 \mathrm{~h}$ after treatment when the diarrhoea had ceased. Subsequently, they were found in the faeces of most of the calves, usually in numbers lower than those of $E$. coli $\mathrm{B} 41$. Very low numbers of $E$. coli $\mathrm{B} 41, \mathrm{~K}^{-}$phage-resistant mutants of B41 and phage B41/1 were found in the alimentary tract of all of six calves examined 4-8 d after treatment; the numbers of $E$. coli $\mathrm{B} 41$ and its mutants were much lower than those of the total E. coli.

The results of counts on the contents of the small intestine of pairs of twin calves at different times after the onset of $E$. coli $\mathrm{B} 41$ diarrhoea when one of each pair had been given $10^{5}$ viable organisms of phage B41/1 are summarized in Table 4. Colostrum-deprived calves were included in this study so that the effect of the phage could be assessed unaugmented by the antibacterial activity of colostral immunoglobulins; twins were used to make comparisons between single animals more reliable. High numbers of phage B41/1 were found throughout the small intestine of the treated colostrum-deprived calf examined $6 \mathrm{~h}$ after the onset of diarrhoea. E. coli B41 was 
Table 4. Counts on the contents of the small intestine of pairs of twin colostrum-deprived $(C D)$ or colostrum-fed $(C F)$ calves infected with $E$. coli B4I, one of each pair being given $10^{5}$ viable organisms of phage B41/1 at the onset of diarrhoea, and examined at different times thereafter

\begin{abstract}
The numbers of $E$. coli B41, non-pathogenic $E$. coli $\mathrm{P} 713$ and lactobacilli given were as for Table 2. Calves examined at the same time after the onset of diarrhoea and of the same colostral status (CD or CF) were twins; those not given phage are marked ${ }^{*}$. The twin of the treated CF calf examined $40 \mathrm{~h}$ after the onset of diarrhoea had died from $E$. coli B4l diarrhoea but was unsuitable for detailed microbiological examination. The CD calf examined $3 \mathrm{~h}$ after the onset of diarrhoea was not a twin; unlike the others it had had diarrhoea for some time before it was treated.
\end{abstract}

\begin{tabular}{|c|c|c|c|c|c|c|c|c|}
\hline \multirow[b]{2}{*}{$\begin{array}{l}\text { Time after onset } \\
\text { of diarrhoea }(\mathrm{h})\end{array}$} & \multirow[b]{2}{*}{$\begin{array}{l}\text { Organisms } \\
\text { enumerated }\end{array}$} & \multicolumn{7}{|c|}{$\begin{array}{l}\left.\text { No. of organisms }\left(\log _{10}[\text { no. (g contents) })^{-1}\right]\right) \text { in } \\
\text { small intestine, part: }\end{array}$} \\
\hline & & T & 2 & 3 & 4 & 5 & 6 & 7 \\
\hline $6(\mathrm{CD})$ & $\begin{array}{l}E . \text { coli } \text { B41 } \\
\mathrm{K}^{-} \text {mutants } \dagger \\
\text { Phage B4l/1 }\end{array}$ & $\begin{array}{r}5.0 \\
<3.0 \\
3.6\end{array}$ & $\begin{array}{r}5.3 \\
<3.0 \\
4.5\end{array}$ & $\begin{array}{r}5.4 \\
<3.0 \\
5.2\end{array}$ & $\begin{array}{l}7 \cdot 4 \\
4 \cdot 8 \\
9 \cdot 8\end{array}$ & $\begin{array}{l}7 \cdot 5 \\
5 \cdot 0 \\
9.8\end{array}$ & $\begin{array}{r}8 \cdot 2 \\
5 \cdot 6 \\
10 \cdot 0\end{array}$ & $\begin{array}{r}8.4 \\
5 \cdot 6 \\
10 \cdot 0\end{array}$ \\
\hline $6(\mathrm{CD})^{*}$ & E. coli B41 & 6.0 & 5.8 & 8.8 & $9 \cdot 2$ & $9 \cdot 3$ & 9.5 & $9 \cdot 5$ \\
\hline $12(\mathrm{CD})$ & $\begin{array}{l}\text { E. coli } \mathrm{B} 41 \\
\mathrm{~K}^{-} \text {mutants } \dagger \\
\text { Phage B41/1 }\end{array}$ & $\begin{array}{r}4.2 \\
<3.0 \\
2.6\end{array}$ & $\begin{array}{r}4.6 \\
<3.0 \\
2.3\end{array}$ & $\begin{array}{r}4.6 \\
<3.0 \\
4.8\end{array}$ & $\begin{array}{l}4 \cdot 2 \\
4 \cdot 5 \\
6 \cdot 0\end{array}$ & $\begin{array}{l}5 \cdot 5 \\
6 \cdot 5 \\
9 \cdot 3\end{array}$ & $\begin{array}{l}6 \cdot 5 \\
6 \cdot 7 \\
9 \cdot 9\end{array}$ & $\begin{array}{l}7 \cdot 3 \\
7 \cdot 5 \\
9 \cdot 4\end{array}$ \\
\hline $12(\mathrm{CD})^{*}$ & E. coli $\mathrm{B} 41$ & $<3.0$ & 5.9 & $8 \cdot 6$ & $9 \cdot 4$ & $9 \cdot 3$ & $9 \cdot 0$ & $9 \cdot 0$ \\
\hline $24(\mathrm{CD})$ & $\begin{array}{l}E . \text { coli } \mathrm{B} 41 \\
\mathrm{~K}^{-} \text {mutants } \dagger \\
\text { Phage B41/1 }\end{array}$ & $\begin{array}{l}4 \cdot 9 \\
6 \cdot 3 \\
7 \cdot 2\end{array}$ & $\begin{array}{l}4 \cdot 8 \\
5 \cdot 8 \\
5 \cdot 2\end{array}$ & $\begin{array}{l}4 \cdot 4 \\
6 \cdot 8 \\
6 \cdot 5\end{array}$ & $\begin{array}{r}<4.0 \\
8.6 \\
6.9\end{array}$ & $\begin{array}{l}6 \cdot 2 \\
9 \cdot 2 \\
7 \cdot 7\end{array}$ & $\begin{array}{l}7 \cdot 2 \\
9 \cdot 5 \\
7 \cdot 9\end{array}$ & $\begin{array}{l}7 \cdot 4 \\
9 \cdot 5 \\
7 \cdot 2\end{array}$ \\
\hline $24(\mathrm{CD})^{*}$ & E. coli B41 & $9 \cdot 3$ & 9.7 & 9.8 & 9.7 & $9 \cdot 7$ & $9 \cdot 5$ & $9 \cdot 7$ \\
\hline 24 (CF) & $\begin{array}{l}\text { E. coli B41 } \\
\mathrm{K}^{-} \text {mutants } \\
\text { Phage B41/1 }\end{array}$ & $\begin{array}{r}3.0 \\
<2.5 \\
4.3\end{array}$ & $\begin{array}{r}3.0 \\
<2.5 \\
3.0\end{array}$ & $\begin{array}{r}4.5 \\
<2.5 \\
5.3\end{array}$ & $\begin{array}{l}4 \cdot 8 \\
6 \cdot 2 \\
6 \cdot 9\end{array}$ & $\begin{array}{l}5 \cdot 3 \\
7 \cdot 6 \\
7 \cdot 5\end{array}$ & $\begin{array}{l}5 \cdot 0 \\
8 \cdot 3 \\
7 \cdot 4\end{array}$ & $\begin{array}{l}6 \cdot 0 \\
7 \cdot 3 \\
7 \cdot 3\end{array}$ \\
\hline $24(\mathrm{CF})^{*}$ & E. coli $\mathrm{B} 41$ & $7 \cdot 0$ & $7 \cdot 0$ & $9 \cdot 2$ & $8 \cdot 6$ & $9 \cdot 2$ & 8.8 & $8 \cdot 6$ \\
\hline $40(\mathrm{CF})$ & $\begin{array}{l}E \text {. coli } \mathrm{B} 41 \\
\mathrm{~K}^{-} \text {mutants } \dagger \\
\text { Phage B41/1 }\end{array}$ & $\begin{array}{l}<2.5 \\
<2.5 \\
<2.5\end{array}$ & $\begin{array}{l}<2.5 \\
<2.5 \\
<2.5\end{array}$ & $\begin{array}{l}<2.5 \\
<2.5 \\
<2.5\end{array}$ & $\begin{array}{l}<2.5 \\
<2.5 \\
<2.5\end{array}$ & $\begin{array}{l}<2.5 \\
<2.5 \\
<2.5\end{array}$ & $\begin{array}{l}<2.5 \\
<2.5 \\
<2.5\end{array}$ & $\begin{array}{r}2.5 \\
<2.5 \\
<2.5\end{array}$ \\
\hline $3(\mathrm{CD})$ & $\begin{array}{l}\text { E. coli } \mathrm{B} 41 \\
\text { Phage B41/1 }\end{array}$ & $\begin{array}{l}6.8 \\
8.0\end{array}$ & $\begin{array}{l}7.0 \\
9.8\end{array}$ & $\begin{array}{l}8.9 \\
8.5\end{array}$ & $\begin{array}{l}9.4 \\
8.3\end{array}$ & $\begin{array}{l}9.4 \\
6.5\end{array}$ & $\begin{array}{l}9.0 \\
5.8\end{array}$ & $\begin{array}{l}8.8 \\
3.7\end{array}$ \\
\hline
\end{tabular}

† Resistant to phage B41/1; no such organisms were found in the untreated calves.

present in much lower numbers in this calf than in its untreated twin examined at this time. This difference between twins was even more apparent in those examined 12 and $24 \mathrm{~h}$ after the onset of diarrhoea, the decline in numbers of $E$. coli B41 in the treated calves with time being accompanied by a decline in the numbers of phage B41/1. By contrast, the numbers of $\mathrm{K}^{-}$phage B41/1-resistant mutants of $E$. coli B41, low in the treated calf examined at $6 \mathrm{~h}$, were higher in the one examined at $12 \mathrm{~h}$ and much higher in the one examined at $24 \mathrm{~h}$. A great difference in numbers of $E$. coli $\mathrm{B} 41$ was also noted between the colostrum-fed twins examined $24 \mathrm{~h}$ after the onset of diarrhoea. No $\mathrm{K}^{-}$phage B41/1-resistant mutants of $E$. coli B41 were found in the anterior small intestine of the treated twin and only moderately high ones in its posterior small intestine, a contrast with the treated colostrum-deprived calf examined at this time. Very few $E$. coli $\mathrm{B} 41$, its $\mathrm{K}^{-}$phage-resistant mutants or phage B41/1 were found in the treated colostrum-fed calf examined at $40 \mathrm{~h}$ after the onset of diarrhoea; the twin control for this calf had died from $E$. coli B41 infection but was unsuitable for detailed bacteriological examination. The results of examining an E. coli B41-infected calf $3 \mathrm{~h}$ after treatment are included at the end of Table 4 to illustrate the rapidity with which phage B41/1 can proliferate in a small intestine heavily infected with $E$. coli B41; this calf had had diarrhoea for some time and was seriously ill when treated. As expected in a so recently treated calf the greatest phage multiplication had occurred in the anterior small intestine. 
Table 5. Effect of giving E. coli B85 and phages of different in vitro virulence to calves

Calves were given $10^{5}$ viable organisms of phage $\mathrm{B} 85 / 1$ or $\mathrm{B} 85 / 2$ or of each of phages $\mathrm{B} 85 / 3, \mathrm{~B} 85 / 4$, $\mathrm{B} 85 / 5, \mathrm{~B} 85 / 6$ and $\mathrm{B} 85 / 7 ; 10$ min later they were given $E$. coli $\mathrm{B} 85$, non-pathogenic $E$. coli $\mathrm{P} 713$ and lactobacilli as in Table 2. Phages B85/1 and B85/2 had the same degree of in vitro virulence; the other phages were all of lower virulence (Table 1).

\begin{tabular}{|c|c|c|c|c|c|}
\hline \multirow[b]{2}{*}{$\begin{array}{l}\text { Phage(s) } \\
\text { given }\end{array}$} & \multirow[b]{2}{*}{$\begin{array}{l}\text { No. of } \\
\text { calves }\end{array}$} & \multirow{2}{*}{$\begin{array}{l}\text { No. that } \\
\text { developed } \\
\text { diarrhoea }\end{array}$} & \multirow[b]{2}{*}{$\begin{array}{l}\text { No. that } \\
\text { died }\end{array}$} & \multicolumn{2}{|c|}{ Diarrhoea } \\
\hline & & & & Character* & $\begin{array}{c}\text { Approx. } \\
\text { duration }(h)^{*}\end{array}$ \\
\hline B85/1 & 6 & 5 & 0 & $\begin{array}{l}\text { Moderate (3), } \\
\text { Mild (2) }\end{array}$ & $\begin{array}{l}12(2), 16 \\
24,40\end{array}$ \\
\hline B85/2 & 4 & 0 & 0 & - & - \\
\hline $\begin{array}{l}\text { B85/3, } 4,5,6 \\
\text { and } 7\end{array}$ & 3 & 3 & 3 & Severe (3) & Until death (3) \\
\hline None & 6 & 6 & 6 & Severe (6) & Until death (6) \\
\hline
\end{tabular}

Effect of giving phages of different in vitro virulence to $E$. coli-infected calves

The clinical disease in calves given a mixture containing $10^{5}$ viable organisms of each of five phages of low in vitro virulence (nos B85/3, 4, 5, 6 and 7; Table 1) $10 \mathrm{~min}$ before they were infected with $E$. coli $\mathrm{B} 85$ was no less severe than that in infected calves not given phage (Table 5). By contrast, calves given one or other of two phages of higher in vitro virulence, phages B85/1 and B85/2, did not exhibit signs of general ill-health, e.g. dehydration. Although both phages reacted identically in the in vitro virulence tests (Table 1 ), five of the six calves given $B 85 / 1$, but none of the four given B85/2, developed moderate or mild diarrhoea which persisted in varying degrees for $12-40 \mathrm{~h}$. An additional two infected calves given $10^{5}$ viable organisms of a mixture of phages B85/1 and B85/2, like the four given B85/2, did not develop diarrhoea.

At point of death, high $E$. coli B85 counts, as high as those in the control calves (Table 3), were found throughout the small intestine of the three calves given the low-virulence phages. Virtually no phage organisms were found in any part of the alimentary tract, except the rectum, of two of these calves. They were found in most parts of the tract in the third calf but in numbers about ten times lower than the numbers of $E$. coli B85 organisms. Similar numbers of viable $E$. coli B85 organisms, approximately $\left(\log _{10} \mathrm{~g}^{-1}\right) 9 \cdot 0$, were found in the routine examinations performed on the faeces of both the calves given the low-virulence phages and the control calves. Much lower numbers of these organisms were present in the faeces of the calves given phage B85/1 or B85/2, the numbers being no higher in those given phage B85/1 that developed diarrhoea than in those given phage B85/2 that did not. $\mathrm{K}^{-}$phage-resistant mutants of $E$. coli B85 were found in most of the faecal examinations on the calves given phage B85/1 in numbers rather similar to those of the $E$. coli B85 organisms but they were not found in any of the faecal examinations on the calves given phage B85/2. The numbers of phage organisms in the faeces of the calves 30-72 $\mathrm{h}$ after they had been given phage B85/1 were about ten times greater than they were in the calves given phage B85/2. This suggests that initial inadequate control of the multiplication of $E$. coli $\mathrm{B} 85$ organisms might have been responsible for the diarrhoea that occurred in the calves given phage B85/1, the diarrhoea either being caused by the $E$. coli B85 organisms themselves and/or by the greater opportunity of substantial numbers of $\mathrm{K}^{-}$phageresistant mutants to emerge.

\section{Effect of giving different doses of phage to calves at different times before or after they were given different doses of $E$. coli}

Giving doses of $10^{5}$ viable organisms of phage B $117 / 1$ to calves $6 \mathrm{~h}$ before they were given the standard infective dose of $10^{9}$ viable organisms of $E$. coli B117 protected them against the development of diarrhoea (calves nos 1-4, Table 6). A lower dose of $10^{2}$ viable phage organisms did not protect (nos 5 and 6); it was also ineffective in two calves to which it was given $3 \mathrm{~h}$ before 
Table 6. Effect of giving different doses of phage B117/1 and E. coli B117 to calves at different times

The calves were given the non-pathogenic $E$. coli $\mathrm{P} 713$ and lactobacilli in the dosage shown in Table 2 at the same time as $E$. coli $\mathrm{B} 117$.

\begin{tabular}{|c|c|c|c|c|c|c|}
\hline \multirow[b]{2}{*}{$\begin{array}{c}\text { Calf } \\
\text { no. }\end{array}$} & \multirow{2}{*}{$\begin{array}{l}\text { Time of phage } \\
\text { administration in } \\
\text { relation to } \\
E \text {. coli } \\
\text { administration }\end{array}$} & \multicolumn{2}{|c|}{$\begin{array}{l}\text { No. of viable } \\
\text { organisms given }\end{array}$} & \multirow{2}{*}{$\begin{array}{l}\text { Subsequent } \\
\text { condition of } \\
\text { calf }\end{array}$} & \multicolumn{2}{|c|}{$\begin{array}{l}\text { No. of viable organisms } \\
\left(\log _{10} \mathrm{~g}^{-1}\right) \text { in part } 7 \text { of the } \\
\text { small intestine approx. } 42 \mathrm{~h} \\
\text { after } E \text {. coli administration }\end{array}$} \\
\hline & & $\begin{array}{l}\text { Phage } \\
\text { B117/1 }\end{array}$ & $\begin{array}{l}\text { E. coli } \\
\text { B } 117\end{array}$ & & Phage 117/1 & E. coli $\mathrm{B} 117$ \\
\hline 1 & $6 \mathrm{~h}$ before & $10^{5}$ & $10^{9}$ & Normal & $5 \cdot 0$ & 5.0 \\
\hline 2 & $6 \mathrm{~h}$ before & $10^{5}$ & $10^{9}$ & Normal & $4 \cdot 5$ & $4 \cdot 6$ \\
\hline 3 & $6 \mathrm{~h}$ before & $10^{5}$ & $10^{9}$ & Normal & 6.7 & 6.7 \\
\hline 4 & $6 \mathrm{~h}$ before & $10^{5}$ & $10^{9}$ & Normal & $7 \cdot 5$ & $7 \cdot 0$ \\
\hline 5 & $6 \mathrm{~h}$ before & $10^{2}$ & $10^{9}$ & Diarrhoea (M) & $8 \cdot 2$ & $6 \cdot 7$ \\
\hline 6 & $6 \mathrm{~h}$ before & $10^{2}$ & $10^{9}$ & Diarrhoea* & 8.7 & 7.7 \\
\hline 7 & $3 \mathrm{~h}$ before & $10^{5}$ & $10^{9}$ & Normal & $5 \cdot 0$ & $6 \cdot 3$ \\
\hline 8 & $3 \mathrm{~h}$ before & $10^{2}$ & $10^{9}$ & Diarrhoea (S) & $5 \cdot 3$ & 6.0 \\
\hline 9 & $3 \mathrm{~h}$ before & $10^{2}$ & $10^{9}$ & Diarrhoea (M) & $<2.0$ & $8 \cdot 6$ \\
\hline 10 & $10 \mathrm{~min}$ before & $10^{2}$ & $10^{9}$ & Normal & $7 \cdot 4$ & $5 \cdot 8$ \\
\hline 11 & $10 \mathrm{~min}$ before & $10^{2}$ & $10^{11}$ & Normal & $7 \cdot 8$ & $5 \cdot 7$ \\
\hline 12 & $10 \mathrm{~min}$ before & $10^{2}$ & $10^{11} \dagger$ & Normal & $4 \cdot 7$ & 4.8 \\
\hline 13 & $6 \mathrm{~h}$ after & $10^{2}$ & $10^{9}$ & Normal & $2 \cdot 8$ & 4.7 \\
\hline 14 & $12 \mathrm{~h}$ after & $10^{2}$ & $10^{9}$ & Normal & $6 \cdot 2$ & $6 \cdot 0$ \\
\hline 15 & $18 \mathrm{~h}$ after & $10^{2}$ & $10^{9}$ & Diarrhoea $(\mathrm{S}) \ddagger$ & $7 \cdot 5$ & 7.2 \\
\hline 16 & $18 \mathrm{~h}$ after & 20 & $10^{9}$ & Diarrhoea (M) $\ddagger$ & $7 \cdot 6$ & $6 \cdot 0$ \\
\hline 17 & - & - & $10^{9}$ & Diarrhoea (S) & - & $9 \cdot 3$ \\
\hline
\end{tabular}

(M), moderate; (S), severe.

* Calf no. 6 was killed and examined microbiologically shortly after the onset of diarrhoea for diagnostic purposes; all the others, except no. 9 and no. 17, the infected control, were normal when they were killed and examined microbiologically $42 \mathrm{~h}$ after $E$. coli administration.

+ Calf no. 12 had been given 10 doses of $10^{10}$ viable organisms of E. coli $\mathrm{B} 117$ at hourly intervals, the first dose 10 min after phage $B 117 / 1$.

$\ddagger$ Calves nos 15 and 16 had diarrhoea when they were given phage B117/1.

infection (nos 8 and 9). This dose was effective when given 10 min before or $6 \mathrm{~h}$ or $12 \mathrm{~h}$ after infection (nos 10-14), including against the massive infecting dose of $10^{11}$ viable organisms (no. 11 ) or 10 doses of $10^{10}$ viable organisms (no. 12) of $E$. coli B117. Even when it did not protect against the development of diarrhoea in the above experiments, it reduced its duration and seriousness in all calves except no. 9 (cf. infected control calf, no. 17, and control calves in Table 2). Amelioration of the disease also occurred when $10^{2}$ or only 20 viable phage organisms were given $18 \mathrm{~h}$ after $E$. coli B117 when diarrhoea was already present (nos 15 and 16). None of the calves, except no. 9 and no. 17, the infected control calf, had abnormally high numbers of $E$. coli B117 or of its $\mathrm{K}^{-}$phage B117/1-resistant mutants in their small intestines when they were examined approximately $42 \mathrm{~h}$ after they had been given $E$. coli B117. The mutants were found in the faeces of most of the phage-treated calves at some stage but never in numbers sufficiently high to indicate that they were playing any part in the disease process. Except for calf no. 9, from which it was never isolated, phage B117/1 was found in the faeces of all the calves to which it was given on the day following administration, the time at which the first faecal examination was usually performed. Its numbers were greatest in the calves with diarrhoea and in the two calves that did not have diarrhoea but had been given large doses of $E$. coli B117 (nos 11 and 12). No phage was detected in the faeces of calf no. $162 \mathrm{~h}$ after it had been given 20 viable phage organisms but, $5 \mathrm{~h}$ later, counts of $\left(\log _{10} \mathrm{~g}^{-1}\right) 8.9$ were found in its faeces. To obtain a better impression of the degree of phage multiplication that may occur in a short time in the infected alimentary tract, a calf with $E$. coli B 117 diarrhoea was given $10^{2}$ viable organisms of phage B117/1 and the total amount of phage organisms in the contents of the different parts of its alimentary tract estimated $5 \mathrm{~h}$ later (Table 7). The total for the whole of the alimentary tract was 
Table 7. Counts, including total phage count, on the contents of the alimentary tract of a calf with $E$. coli B117 diarrhoea, $5 \mathrm{~h}$ after it had been given $10^{2}$ viable organisms of phage B117/1

The diarrhoea was produced by giving the calf $E$. coli $\mathrm{B} 117$, the non-pathogenic $E$. coli $\mathrm{P} 713$ and lactobacilli in the dosage shown in Table 2.

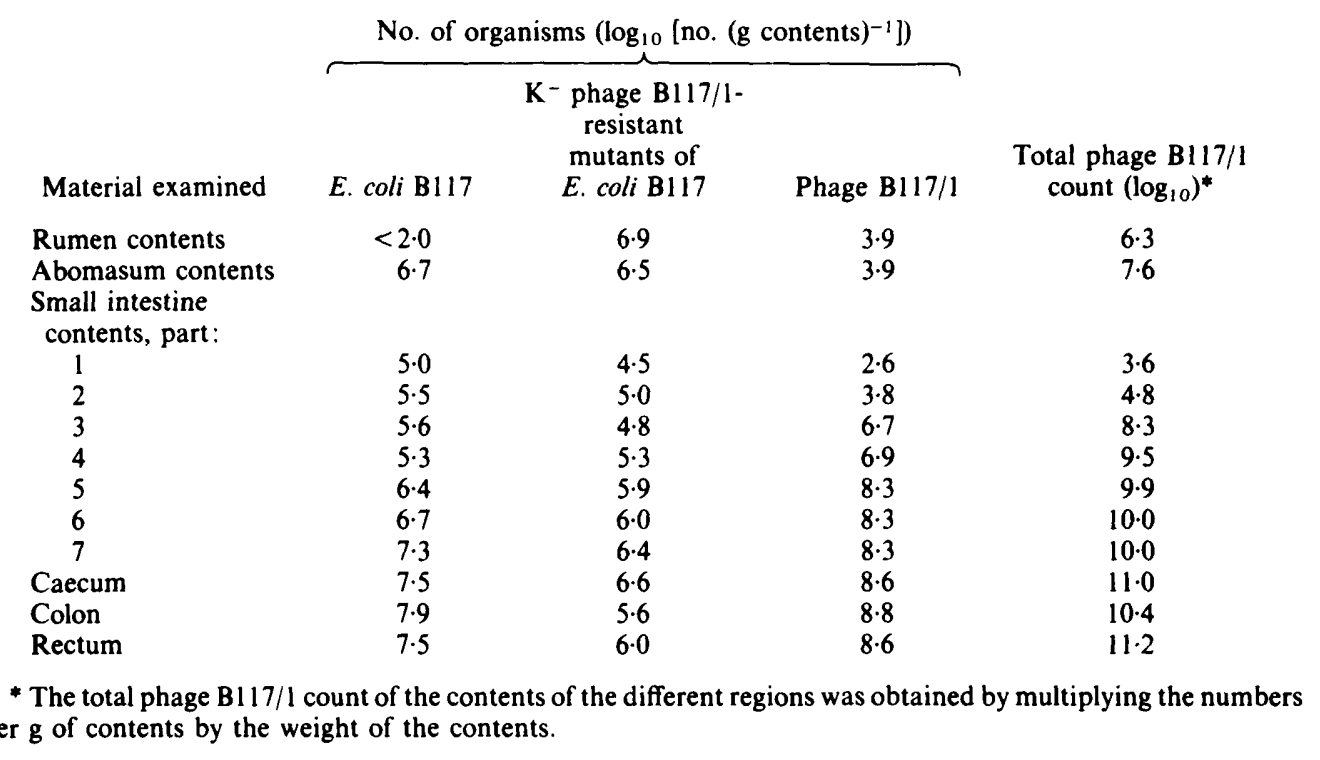

approximately $\left(\log _{10}\right) 11 \cdot 3$, representing an enormous degree of multiplication. The number of $E$. coli B117 organisms in the faeces of this calf when it was given the phage was $\left(\log _{10} g^{-1}\right) 9 \cdot 0$; the corresponding figure $5 \mathrm{~h}$ later was only $7 \cdot 5$. The profound influence that the phage had had on the $E$. coli B 117 population of the alimentary tract in so short a time was also exemplified by the considerable numbers of $\mathrm{K}^{-}$phage $\mathrm{B} 117 / 1$-resistant mutants that were present.

Effect of giving phages in a feed of milk to calves at different times before or after they were infected with $E$. coli

To obtain information as to whether phages might be conveniently used under practical conditions to prevent calves contracting $E$. coli diarrhoea by giving them to calves in one or more of their twice-daily milk feeds, $10^{5}$ viable organisms of phage $S 13 / 2$ in 1.01 of milk were given to seven calves $4 \mathrm{~h}$ before or $2,4,6,8,10$ or $12 \mathrm{~h}$ after they were given $E$. coli $\mathrm{S} 13$. The calves given the phage $4 \mathrm{~h}$ before or 2-8 $\mathrm{h}$ after $E$. coli $\mathrm{S} 13$ remained well and the two given it at 10 or $12 \mathrm{~h}$ after $E$. coli $\mathrm{S} 13$ only suffered mild diarrhoea of short duration, a situation quite different from that in the control calves (Table 2). The numbers of $E$. coli S13 organisms in the faeces of the seven calves were usually much lower than the $\left(\log _{10} g^{-1}\right) 9.0$ or so usually found in the control calves. Another calf which had E. coli $\mathrm{S} 13$ diarrhoea $10 \mathrm{~h}$ after inoculation, to us a uniquely short incubation period, was immediately given phage $S 13 / 2$ in the same manner as the other calves had been given it. The infection ran a very acute course and the calf was near to death $19 \mathrm{~h}$ after inoculation with $E$. coli $\mathrm{S} 13$.

Because the previous experiment indicated that towards the end of the period between the twice-daily feeds was the most critical time for assessing the potential practical value of 'in-feed' phage medication, six calves were given the highly virulent $E$. coli B79 strain followed, $10 \mathrm{~h}$ later, by $10^{5}$ viable organisms of phage B79/2 in 1.01 of milk. Apart from one calf that had moderate diarrhoea for about $12 \mathrm{~h}$, all the calves remained well and at the end of the observation period of $4 \mathrm{~d}$ had only low numbers of $E$. coli B79, $\mathrm{K}^{-}$phage B79/2-resistant mutants of $\mathrm{B} 79$ and phage $B 79 / 2$ in their small intestines. 
Table 8. Counts on the faeces of eight calves given E. coli B4I when they were in a room previously occupied by phage-treated E. coli B4I-infected calves

The calves were given $E$. coli $\mathrm{B} 41$, the non-pathogenic $E$. coli $\mathrm{P} 713$ and lactobacilli in the doses shown in Table 2 . The median counts are given followed by the range, in parentheses.

\begin{tabular}{|c|c|c|}
\hline \multirow{2}{*}{$\begin{array}{c}\text { Time after } \\
\text { being given } \\
\text { E. coli B41 (h) }\end{array}$} & \multicolumn{2}{|c|}{ No. of organisms $\left.\left(\log _{10}[\text { no. (g faeces) })^{-1}\right]\right)$} \\
\hline & E. coli $\mathrm{B} 41$ & Phage B4l/1 \\
\hline $\begin{array}{l}21 \\
24 \\
27 \\
44 \\
68 \\
92\end{array}$ & $\begin{array}{l}6.6(3.3-7.8) \\
6.9(<4.0-8.3) \\
6.9(<4.0-8.2) \\
6.5(6.0-7.8) \\
5.6(5.0-6.2) \\
4.7(<4.0-6.0)\end{array}$ & $\begin{array}{l}7.0(3.0-8.0) \\
7.9(7.6-8.2) \\
7.9(6.9-8.8) \\
7.8(6.7-8.6) \\
6.9(4.4-7.7) \\
6.0(2.5-7.2)\end{array}$ \\
\hline
\end{tabular}

Effect of giving E. coli to calves kept in an uncleaned room previously occupied by phage-treated E. coli-infected calves

Six calves suffering from experimentally produced $E$. coli B4l diarrhoea were given phage B41/1 and then kept in the same room of $12.0 \mathrm{~m}^{2}$ floor area during and after the time they were recovering from the disease. Each calf occupied the room for 5, 5, 5, 6, 8 or $12 \mathrm{~d}$, the total period of occupancy being $35 \mathrm{~d}$. The room was not cleaned and was used for housing another eight calves, the first calf being put in as soon as the room was vacant and the last one $71 \mathrm{~d}$ later. Each calf occupied the room for $4,4,5,5,5,6,6$ or $6 \mathrm{~d}$. After they had been in the room for $3 \mathrm{~h}$ the calves were inoculated with $E$. coli B41 in the usual manner. Apart from one that had mild diarrhoea for $6 \mathrm{~h}$, all the calves remained well, quite a different result from that obtained in infected control calves (Table 2). Fairly high numbers of phage B41/1 were found in the faeces of all eight calves on the day after they had been given $E$. coli B41; before this time, the rectal contents, like those of all normal calves, usually consisted of meconium (Table 8 ). The numbers of $E$. coli B41 in their faeces were nearly always low and never as high as the $\left(\log _{10} g^{-1}\right) 9.0$ or so found in control infected calves. $\mathrm{K}^{-}$phage B41/1-resistant mutants of $E$. coli B41 appeared in the faeces of all the calves $30 \mathrm{~h}$ after inoculation. They continued to be isolated at most of the subsequent faecal examinations, but rarely in high numbers. The phage B41/1 content of the litter in the room was monitored throughout the period it was occupied by the eight calves. The counts obtained in the 15 examinations were $\left(\log _{10} \mathrm{~g}^{-1}\right)$ median 6.3 and range $5 \cdot 2-7 \cdot 0$. There was no tendency for the counts to be higher at the end of the period than at the beginning.

\section{Effect of giving E. coli to calves in rooms whose litter had been sprayed with phage}

Because the results of the previous experiment suggested that distributing phage in the environment might be a convenient and effective method of preventing $E$. coli diarrhoea under natural conditions, six calves, as and when they became available, were put into a room of $12.0 \mathrm{~m}^{2}$ floor area in which the litter had been sprayed with an aqueous suspension of $\left(\log _{10}\right) 10 \cdot 3$ viable organisms of phage B41/1. Another four were put in a similar sized room whose litter had been sprayed with a suspension containing only $\left(\log _{10}\right) 6.0$ viable organisms of the phage. Three hours after they were put in the rooms the calves were inoculated with $E$. coli B41 in the usual manner. The six calves in the first experiment occupied their room for 4, 5, 5, 5, 5 or $7 \mathrm{~d}$ during a period of $16 \mathrm{~d}$; the four calves in the second experiment occupied their room for $5,6,6$ or $6 \mathrm{~d}$ during a period of $19 \mathrm{~d}$. None of the 10 calves developed diarrhoea. Similar results were obtained in the examination of post-infection faecal samples obtained from the calves in both rooms. As soon as sizeable numbers of $E$. coli B4l were found in the faeces of a calf so were phage B41/1 organisms; the phage numbers were usually 10 to 100 times greater than the $E$. coli $\mathrm{B} 41$ numbers. The median of the counts $\left(\log _{10} \mathrm{~g}^{-1}\right)$ in the faeces of the calves in the first experiment at approximately $37,45,60,70,85$ and $95 \mathrm{~h}$ after inoculation with $E$. coli B41 were (E. coli B41 first followed by phage in parentheses) $5.9(7 \cdot 1), 6 \cdot 3(7.5), 5 \cdot 4(7.0), 4 \cdot 8(6.9), 5.6(5.8)$ and $4 \cdot 2(5 \cdot 2)$, 
Table 9. Counts at different times after inoculation with E. coli B44 on small intestinal contents of calves kept in phage B44/4-sprayed or unsprayed rooms

Each of eight calves was put in a separate room in which the litter had, or had not, been sprayed with an aqueous suspension of $10^{10}$ viable organisms of phage $B 44 / 4 ; 3$ h later they were inoculated with $E$. coli B44, the non-pathogenic E. coli $\mathrm{P} 713$ and the lactobacillus strain in the dosage shown in Table 2 . The results quoted are those for each calf.

\begin{tabular}{|c|c|c|c|c|c|c|c|c|c|}
\hline \multirow{2}{*}{$\begin{array}{c}\text { Time after } \\
\text { inoculation }(\mathrm{h})\end{array}$} & \multirow{2}{*}{$\begin{array}{l}\text { Phage } \\
\text { exposed }\end{array}$} & \multirow{2}{*}{$\begin{array}{l}\text { Organisms } \\
\text { enumerated }\end{array}$} & \multicolumn{7}{|c|}{$\begin{array}{l}\left.\text { No. of organisms }\left(\log _{10} \text { [no. (g contents) }\right)^{-1}\right] \text { ) in } \\
\text { small intestine, part } * \text { : }\end{array}$} \\
\hline & & & 1 & 2 & 3 & 4 & 5 & 6 & 7 \\
\hline 24 & Yes & $\begin{array}{l}\text { E. coli } \text { B } 44 \\
\text { Phage B44/4 }\end{array}$ & $\begin{array}{l}2 \cdot 7 \\
3 \cdot 5\end{array}$ & $\begin{array}{l}3 \cdot 3 \\
3 \cdot 7\end{array}$ & $\begin{array}{l}3 \cdot 8 \\
5 \cdot 5\end{array}$ & $\begin{array}{l}4 \cdot 6 \\
6 \cdot 2\end{array}$ & $\begin{array}{l}4 \cdot 7 \\
6 \cdot 5\end{array}$ & $\begin{array}{l}4.5 \\
6.5\end{array}$ & $\begin{array}{l}6.0 \\
7.8\end{array}$ \\
\hline 24 & No & E. coli $\mathrm{B} 44$ & 6.0 & $5 \cdot 7$ & $9 \cdot 2$ & $9 \cdot 3$ & $9 \cdot 5$ & $9 \cdot 3$ & 9.7 \\
\hline 30 & Yes & $\begin{array}{l}E . \text { coli } \mathrm{B} 44 \\
\text { Phage B44/4 } \\
\text { E. coli } \mathrm{B} 44\end{array}$ & $\begin{array}{r}<2.0 \\
2.0 \\
5.5\end{array}$ & $\begin{array}{l}3 \cdot 0 \\
3 \cdot 5 \\
7 \cdot 7\end{array}$ & $\begin{array}{l}4 \cdot 8 \\
5 \cdot 2 \\
8 \cdot 8\end{array}$ & $\begin{array}{l}5 \cdot 0 \\
7 \cdot 8 \\
8 \cdot 8\end{array}$ & $\begin{array}{l}4 \cdot 2 \\
8 \cdot 0 \\
8 \cdot 8\end{array}$ & $\begin{array}{l}5 \cdot 3 \\
8 \cdot 2 \\
9 \cdot 9\end{array}$ & $\begin{array}{l}6 \cdot 0 \\
8 \cdot 5 \\
9 \cdot 0\end{array}$ \\
\hline 40 & Yes & $\begin{array}{l}\text { E. coli } \text { B44 } \\
\text { Phage } \text { B44/4 } \\
\text { E. coli } \text { B44 }\end{array}$ & $\begin{array}{r}<2.0 \\
<2.0 \\
3.2\end{array}$ & $\begin{array}{r}<2.0 \\
<2.0 \\
8.5\end{array}$ & $\begin{array}{r}<2.0 \\
2.8 \\
9.7\end{array}$ & $\begin{array}{l}2.5 \\
3.0 \\
9.8\end{array}$ & $\begin{array}{r}3 \cdot 2 \\
3 \cdot 3 \\
10 \cdot 0\end{array}$ & $\begin{array}{r}3.5 \\
5.4 \\
10.0\end{array}$ & $\begin{array}{r}4.6 \\
7.8 \\
10 \cdot 0\end{array}$ \\
\hline 48 & Yes & $\begin{array}{l}\text { E. coli B44 } \\
\text { Phage B } 44 / 4\end{array}$ & $\begin{array}{l}<2.0 \\
<2.0\end{array}$ & $\begin{array}{l}<2 \cdot 0 \\
<2 \cdot 0\end{array}$ & $\begin{array}{l}2 \cdot 3 \\
2 \cdot 3\end{array}$ & $\begin{array}{l}2 \cdot 5 \\
2 \cdot 3\end{array}$ & $\begin{array}{l}4.0 \\
3.5\end{array}$ & $\begin{array}{l}4.2 \\
3.7\end{array}$ & $\begin{array}{l}5.0 \\
7.5\end{array}$ \\
\hline 48 & No & E. coli B44 & $3 \cdot 5$ & $5 \cdot 7$ & $9 \cdot 2$ & 9.8 & $10 \cdot 0$ & $10 \cdot 0$ & $10 \cdot 0$ \\
\hline
\end{tabular}

- The numbers of $E$. coli $\mathrm{B} 44$ and phage B $44 / 4$ in the abomasum resembled those in part 1 of the small intestine; the numbers in the colon and rectum resembled those in part 7.

respectively. Corresponding figures for the calves in the second experiment were $6.0(7 \cdot 0), 6.0$ $(7.7), 5.8(7.4), 5.6(7.4), 5.0(7.2)$ and $4.3(7.0)$, respectively. Very few of the faecal specimens were found to contain $\mathrm{K}^{-}$phage B41/1-resistant mutants of $E$. coli B41; when they were found their numbers were low. Counts of phage B41/1 in the litter of the calves in the first experiment 0 , $3,6,10$ and $15 \mathrm{~d}$ after its commencement were $\left(\log _{10} \mathrm{~g}^{-1}\right), 5 \cdot 7,4 \cdot 2,6 \cdot 0,5 \cdot 4$ and 6.4, respectively.

The experiments with $E$. coli B41 and phage B41/1 were repeated with $E$. coli B44 and phage B 44/4 but this time the calves were all kept in different rooms of $6.0 \mathrm{~m}^{2}$ floor space that had been sprayed with $10^{10}$ viable organisms of phage B44/4. The litter counts of phage B44/4 in these rooms at the time the calves were put into them were $\left(\log _{10} g^{-1}\right) 5 \cdot 0-5 \cdot 6$. Nine calves were used in this experiment. Eight of them remained well and one had an attack of mild/moderate diarrhoea of about $24 \mathrm{~h}$ duration. When the calves were killed, $4 \mathrm{~d}$ after they had been put under experiment, only low numbers of $E$. coli B44 and low or moderate numbers of phage B44/4 were found throughout their small intestines. The microbiological examinations on the faeces of these calves yielded results closely similar to those obtained in the case of the $E$. coli B41-infected calves with the exception that high numbers of $E$. coli $\mathrm{B} 44$ were found in the faeces of the unwell calf during its diarrhoeic episode.

To follow the course of events after calves in phage B44/4-sprayed rooms are inoculated with $E$. coli B44, four additional calves were examined at different times after inoculation and the results compared with those obtained for similarly inoculated calves kept in unsprayed rooms (Table 9). Only low numbers of $E$. coli B44 were found throughout the small intestine of the two calves kept in phage-sprayed rooms and examined $24 \mathrm{~h}$ or $30 \mathrm{~h}$ after inoculation with $E$. coli B44, very much lower than those found in the corresponding calves kept in unsprayed rooms. Phage B44/4 organisms were found throughout the small intestine of the two calves; in its lower half they were about 100 times more numerous than $E$. coli B44 in the calf examined at $24 \mathrm{~h}$ and about 1000 times more numerous than $E$. coli B44 in the one examined at $30 \mathrm{~h}$. The numbers of $E$. coli B44 organisms in the small intestine of the two calves kept in phage-sprayed rooms and examined 40 or $48 \mathrm{~h}$ after inoculation were even lower than those found in the two examined at 24 or $29 \mathrm{~h}$; the numbers of phage B44/4 organisms present, too, were very much lower. 
Table 10. Effect of giving mixtures of six E. coli strains and mixtures of six phages active on them to calves by different methods

Calves in groups A, B and C were given orally $2 \times 10^{8}$ viable organisms of each of $E$. coli B41, B44, B79, B85, B117 and S48 with the non-pathogenic E. coli P713 and the lactobacillus strain in their usual dosage. Group B calves were given, $2 \mathrm{~h}$ later, $10^{5}$ viable organisms of each of the six phages B41/1, B44/4, B79/2, B85/2, B117/1 and S48/1 in 1.0 l of milk. Group C calves were immediately put in a room, floor space $12 \mathrm{~m}^{2}$, whose litter had been sprayed with an aqueous suspension of $2 \times 10^{10}$ viable organisms of each of the six phages. As soon as possible after birth group $D$ and then group $E$ calves were put in the room that had not been cleaned after it had held the group A calves. Group $E$ calves were given $10^{5}$ viable organisms of each of the six phages in 1.01 of milk approx. 5 and $16 \mathrm{~h}$ after they had been put in the room.

\begin{tabular}{|c|c|c|c|c|c|c|c|}
\hline \multirow[b]{2}{*}{ Group } & \multirow{2}{*}{$\begin{array}{l}\text { No. of } \\
\text { calves }\end{array}$} & \multirow[b]{2}{*}{ Treatment } & \multicolumn{3}{|c|}{ No. with diarrhoea } & \multirow{2}{*}{$\begin{array}{l}\text { No. that } \\
\text { died }\end{array}$} & \multirow{2}{*}{$\begin{array}{c}\text { Survival time } \\
\text { of calves that } \\
\text { died }(h)^{*}\end{array}$} \\
\hline & & & Severe & Moderate & Mild & & \\
\hline A & 8 & Given $E$. coli orally & 8 & 0 & 0 & 8 & $\begin{array}{l}24,30,36,40,48(2), \\
65,90\end{array}$ \\
\hline B & 8 & $\begin{array}{l}\text { Given } E \text {. coli and } \\
\text { phages orally }\end{array}$ & 1 & 1 & 2 & 1 & 70 \\
\hline $\mathrm{C}$ & 7 & $\begin{array}{l}\text { Given } E \text {. coli orally and } \\
\text { phages by exposure }\end{array}$ & 0 & 0 & 2 & 0 & \\
\hline D & 6 & $\begin{array}{l}\text { Given } E \text {. coli by } \\
\text { exposure }\end{array}$ & 6 & 0 & 0 & 6 & $25,40(3), 60,65$ \\
\hline $\mathbf{E}$ & 8 & $\begin{array}{l}\text { Given } E \text {. coli by exposure } \\
\text { and phages orally }\end{array}$ & 3 & 1 & 0 & 3 & $40,60,80$ \\
\hline
\end{tabular}

Experiments similar to those with $E$. coli B 44 and phage B $44 / 4$ were now performed with $E$. coli $\mathrm{S} 48$ and phage S48/1 except that the calves, three per treatment, were infected with $E$. coli $\mathrm{S} 48$ at 0,6 or $12 \mathrm{~h}$ before they were put in the phage-sprayed rooms. All six calves inoculated with $E$. coli $\mathrm{S} 48$ at 0 or $6 \mathrm{~h}$ before they were put in the phage-sprayed rooms remained well, but, of the three inoculated $12 \mathrm{~h}$ before, one developed moderate diarrhoea and one mild diarrhoea, the diarrhoea lasting for about $12 \mathrm{~h}$; this was quite different from the results obtained with the control calves (Table 2). Based on faecal examinations, the sequence of events that took place in these calves resembled that in the calves used in the previous phage-spray experiments. $\mathrm{K}^{-}$ phage S48/1-resistant mutants of $E$. coli 448 were commonly found in the faeces of the calves but rarely in numbers greater than those of $E$. coli $\mathrm{S} 48$ itself. When the calves were killed $4 \mathrm{~d}$ after inoculation with $E$. coli S48, $E$. coli S48 and phage $S 48 / 1$ were either not found in their small intestines or were present in very low numbers; $\mathrm{K}^{-}$phage $\mathrm{S48} / 1$-resistant mutants were never found.

In the experiments with $E$. coli $S 48$ and phage $S 48 / 1$ and in all the other experiments so far recorded, no evidence was ever found in any of the calves of extraneous phages active on the $E$. coli strains with which they had been inoculated or of phage-resistant organisms of these strains other than of the $\mathrm{K}^{-}$variety.

\section{Effect of a pool of phages in controlling diarrhoea caused by a mixture of E. coli strains of different serotypes}

The results of infecting calves by different methods with six of the enteropathogenic $E$. coli strains and then treating them by different methods with a mixture of the six phages active on these strains are summarized in Table 10. Of the calves given phages (groups B, C and E), the healthiest at the end of the experiment were those that had been given the $E$. coli orally and then kept in a room whose litter had been sprayed with the phages (group C). E. coli B41 and B44 had proliferated in the small intestine of most of the orally inoculated control calves (group A) and probably were the major cause of their death (Table 11). The other four strains had only proliferated in the small intestine of a few of them, e.g. E. coli B79 in calf 8, B85 in calves 1 and 2, B1 17 in calf 8 and S48 in calves 1,2 and 5. Rather similar results were obtained in the six control calves that acquired infection by being kept in the room previously occupied by the group $A$ 
Table 11. Counts on the contents of part 7 of the small intestine of the calves that died in the experiment featured in Table 10

For details see Table 10.

\begin{tabular}{|c|c|c|c|c|c|c|c|}
\hline \multirow[b]{2}{*}{ Group } & \multirow[b]{2}{*}{ Calf no. } & \multicolumn{6}{|c|}{ No. of organisms $\left.\left(\log _{10} \text { [no. (g contents) }\right)^{-1}\right]$ ) of $E$. coli } \\
\hline & & B41 & B44 & B79 & B85 & B117 & S48 \\
\hline A & $\begin{array}{l}1 \\
2 \\
3 \\
4 \\
5 \\
6 \\
7 \\
8\end{array}$ & $\begin{array}{l}8.4 \\
8.0 \\
8.7 \\
8.5 \\
8.7 \\
7.8 \\
8.2 \\
8.3\end{array}$ & $\begin{array}{l}7.9 \\
8 \cdot 3 \\
8.7 \\
8.5 \\
8.2 \\
8.7 \\
8.4 \\
7.7\end{array}$ & $\begin{array}{l}7 \cdot 7 \\
8 \cdot 0 \\
4 \cdot 3 \\
5 \cdot 6 \\
6 \cdot 2 \\
5 \cdot 5 \\
6 \cdot 2 \\
9.0\end{array}$ & $\begin{array}{l}8.4 \\
8.7 \\
7.7 \\
6.7 \\
6.7 \\
6.3 \\
7.6 \\
7.4\end{array}$ & $\begin{array}{l}6.8 \\
6.6 \\
5.9 \\
5.3 \\
6.2 \\
8.0 \\
6.7 \\
9.3\end{array}$ & $\begin{array}{l}8.4 \\
9 \cdot 3 \\
5.8 \\
5.6 \\
8.6 \\
7.0 \\
5.9 \\
6.0\end{array}$ \\
\hline B & 9 & $9 \cdot 9^{*}$ & $6 \cdot 2$ & $5 \cdot 8$ & $7 \cdot 0$ & $6 \cdot 7$ & $8 \cdot 2^{*}$ \\
\hline D & $\begin{array}{l}10 \\
11 \\
12 \\
13 \\
14 \\
15\end{array}$ & $\begin{array}{l}8 \cdot 3 \\
9 \cdot 4 \\
8 \cdot 6 \\
7 \cdot 8 \\
8 \cdot 3 \\
8 \cdot 3\end{array}$ & $\begin{array}{l}8.9 \\
8.5 \\
8 \cdot 3 \\
7.4 \\
8.5 \\
8.7\end{array}$ & $\begin{array}{l}8 \cdot 0 \\
6 \cdot 3 \\
5 \cdot 5 \\
5 \cdot 0 \\
5 \cdot 0 \\
4 \cdot 9\end{array}$ & $\begin{array}{l}8 \cdot 3 \\
6 \cdot 8 \\
5 \cdot 7 \\
4 \cdot 5 \\
6 \cdot 2 \\
6 \cdot 2\end{array}$ & $\begin{array}{l}8.6 \\
6.0 \\
7.7 \\
8.7 \\
6.5 \\
5.7\end{array}$ & $\begin{array}{l}4.0 \\
4 \cdot 2 \\
3.6 \\
4 \cdot 8 \\
4 \cdot 2 \\
3.9\end{array}$ \\
\hline $\mathbf{E}$ & $\begin{array}{l}16 \\
17 \\
18\end{array}$ & $\begin{array}{l}6 \cdot 2 \\
7 \cdot 2 \\
5 \cdot 5\end{array}$ & $\begin{array}{l}7.9 \\
6.0 \\
7.0\end{array}$ & $\begin{array}{l}8.7 \dagger \\
9.9 \dagger \\
8.7 \dagger\end{array}$ & $\begin{array}{l}5 \cdot 9 \\
7 \cdot 2 \\
4 \cdot 3\end{array}$ & $\begin{array}{l}5 \cdot 2 \\
8 \cdot 7^{*} \\
5 \cdot 2\end{array}$ & $\begin{array}{l}5.4 \\
5.0 \\
4.9\end{array}$ \\
\hline
\end{tabular}

calves (group D) except that only low numbers of $E$. coli $\mathrm{S} 48$ were present in their alimentary tracts; in some of the examinations they were too low to be detected. Low counts of $E$. coli S48, too, had been obtained in the twice-daily faecal examinations of these calves, an observation that correlated with the discovery that the calves were contaminated with a phage active on $E$. coli S48. Phage counts on these faecal samples and on the alimentary tract contents revealed the phage (designated S48/2) often to be present in much greater numbers than $E$. coli S48. This, together with the observation that many of the $E$. coli $\mathrm{S} 48$ isolates made from the calves were of the $\mathrm{K}^{-}$phage-resistant variety, left no doubt that the phage was effectively controlling the multiplication of $E$. coli 448 organisms in them. Phage S48/2, which could be distinguished from phage $\$ 48 / 1$ by plaque morphology, was detected in all of the next group of calves that occupied this uncleaned room (group E), sometimes in numbers greater than that of phage S48/1 which the calves had been given with the other five phages in doses of $10^{5}$ viable organisms on two occasions. It was also found in the fourth faecal sample of the third calf and in all the samples of the subsequent calves that were given the $E$. coli strains orally and then kept in a phage-sprayed room (group C); in most of these samples phage S48/2 organisms were at least 100 times more numerous than phage $\mathrm{S} 48 / 1$ organisms. In in vitro tests phage $\mathrm{S} 48 / 2$ was slightly less virulent at $37^{\circ} \mathrm{C}$, but more virulent at $40^{\circ} \mathrm{C}$, than phage S48/1 (Table 1). Phage S48/2 was unusual in that it could not replicate in broth cultures unless $\mathrm{CaCl}_{2}$ was added to them. This effectively precluded its being one of the anti-E. coli $\mathrm{S} 48$ phages we had isolated in our phage searches because $\mathrm{CaCl}_{2}$ supplemented broth had not been used for that purpose. It was only detected in the calves in these experiments because their phage counts were performed on nutrient agar to which $\mathrm{CaCl}_{2}$ was routinely added; its source remained a mystery.

The three calves that died in group $\mathrm{E}$, the group given the phages orally after being put in the uncleaned room, were the last three to occupy it. They had large numbers of $\mathrm{K}^{+}$phage B79/2resistant mutants of $E$. coli $\mathrm{B} 79$ throughout the middle and lower regions of their small intestines which most probably were responsible for their death. Although the $\mathrm{K}^{+}$phage B79/2-resistant mutants of $E$. coli $\mathrm{B} 79$ were colonially indistinguishable from phage-sensitive organisms of this 
strain, they were immediately suspected of being phage-resistant because the phage B79/2 counts of the alimentary tract contents of the three calves in which the mutants were present in high numbers were very low - a very unusual relationship to find between phage-sensitive bacteria and highly virulent phages. Phage resistance was also demonstrated in $\mathrm{K}^{+} E$. coli $\mathrm{B} 79$ isolates from another two calves in group $\mathrm{B}$ and from two calves in group $\mathrm{C}$ and in $\mathrm{K}^{+}$isolates of $E$. coli B41 and B85 from one calf in each of groups B and C; all these calves were healthy.

\section{Studies on phage-resistant mutants of the E. coli strains}

$K^{-}$phage-resistant mutants. These mutants were common in broth cultures of the six $E$. coli strains used in the mixed infection experiments. Counting one such culture of each of the strains on plain nutrient agar and on nutrient agar layered with a concentrated suspension of the phage active on that particular strain indicated the ratio of $\mathrm{K}^{-}$phage-resistant organisms to $\mathrm{K}^{+}$ organisms present to be 1 in 1000 to 1 in 10000 .

The relative inability of the $\mathrm{K}^{-}$mutants to colonize the small intestine was demonstrated in three calves given mixtures of equal numbers of organisms of the six strains and of their $\mathrm{K}^{-}$ phage-resistant mutants and examined when suffering from severe diarrhoea. Similar numbers of the strains and their mutants were found in the abomasum of the calves but in the small intestines the six strains greatly out-numbered their mutants; in most parts of the small intestine of all three calves none of the mutants was detected. A mixture of the six mutants was given to six calves. Three remained normal, one had mild diarrhoea for about $10 \mathrm{~h}$, another had mild/moderate diarrhoea for about $20 \mathrm{~h}$ and the remaining one had severe diarrhoea from which it died. The serum of the dead calf reacted only weakly in the zinc sulphate immunoglobulin test and so did the whey from a sample of the colostrum which the calf had been given on arrival at the laboratory.

$\mathrm{K}^{+}$phage-resistant mutants. Such mutants were not isolated when broth cultures or phage-lysed broth cultures of the six $E$. coli strains were inoculated onto phage-layered plates. Neither were they detected when the plates were additionally layered with phages active only on $\mathrm{K}^{-}$mutants of the strains. When these procedures were repeated using broth cultures of mixtures of the six strains and the six phages that were active on them as inocula and employing plates of selection media containing, apart from appropriate phages, appropriate antibiotics that enabled only one or other of the six strains to grow upon them, $\mathrm{K}^{+}$phage-resistant isolates of $E$. coli $\mathrm{B} 41$ and $\mathrm{B} 85$ were obtained which appeared to be identical with those that had emerged in vivo.

Three calves were inoculated with equal amounts of either $E$. coli B41, B79 or B85 and its in vivo-isolated $\mathrm{K}^{+}$phage-resistant mutant. The calves were examined during the diarrhoeic phase and the relative numbers of the parent strain and its mutant in the contents of part 7 of the small intestine assessed according to the phage susceptibility of 100-120 isolates of the infecting $E$. coli organisms. The total numbers for the calf given $E$. coli B41 and its mutant $\left(\log _{10} \mathrm{~g}^{-1}\right)$ were $9 \cdot 0$ and 8.9 respectively. The corresponding figures for the calf given $E$. coli $\mathrm{B} 79$ and its mutant were 9.0 and 8.4 and for the calf given B85 and its mutant were 9.2 and 9.3 , results that suggested that the $\mathrm{K}^{+}$mutants were as successful as their parents at colonizing the small intestine.

Mutants of phages B41/1 and B85/2 that were active on the $\mathrm{K}^{+}$phage-resistant mutants of $E$. coli $\mathrm{B} 41$ or $\mathrm{B} 85$ used in the previous experiment were easily obtained by passage of the phages in broth cultures of the bacterial mutants. A similar mutant of phage B79/2 was not obtained by this method but one was obtained by substituting a mixture of other anti-E. coli B79 phages for this phage in the passage experiments. The three mutant phages were also active on all the other $\mathrm{K}^{+}$phage B41/1-, phage B79/2- or phage B85/2-resistant mutants of $E$. coli B41, B79 or B85 that had been isolated in vivo or in vitro and on $E$. coli B41, B79 or B85 themselves.

The therapeutic potential of the three mutant phages was demonstrated by giving three calves equal amounts of one or other of $E$. coli B41, B79 or B85 and its $\mathrm{K}^{+}$phage-resistant mutant and $2 \mathrm{~h}$ later giving them $10^{5}$ viable organisms of the relevant mutant phage. The three calves remained well. Moderately high numbers of the mutant phages were found in their faeces during the $4 \mathrm{~d}$ observation period and at the end of it only very low numbers of the infecting $E$. coli organisms were found in their small intestines. 
DISCUSSION

Low activity in vivo, commonly quoted as a reason for phages having little part to play in the control of disease, was not a feature of the phages we used in the therapeutic studies. This was well illustrated by the rapid and enormous phage multiplication, and the consequent great reduction of susceptible bacteria, that occurred in the alimentary tract of $E$. coli-infected calves given low doses of phage organisms. High activity, too, was responsible for the good disease control obtained in the phage-sprayed rooms, although frequent entry of phage into the alimentary tract in the early stages of infection must also have been important. The in vitro phage virulence tests undoubtedly helped in the selection of suitable phages but they were only an approximate guide, as revealed by the experiments with the anti-E. coli $\mathrm{B} 85$ phages (Table 5). The inclusion of $E$. coli-infected calves in the selection process probably made the greatest contribution. The phages finally chosen did not form lysogenic relationships with host organisms. Their possible field use, therefore, would be free from the objection that they might incorporate undesirable host genes in their genome.

The emergence of phage-resistant organisms is the other main objection raised to the potential use of phages in therapy. Resistant organisms were commonly found in our treated calves but in the infections produced with single $E$. coli strains in this and in our previous work (Smith \& Huggins, 1983) they were all $\mathrm{K}^{-}$. Because of their relative avirulence it seems unlikely that they would pose a serious problem in calves that had received adequate amounts of colostrum. $\mathrm{K}^{+}$ phage-resistant organisms of E. coli B41, B79 and B85, however, were found in some of the calves given mixtures of the six $E$. coli strains and their phages. These mutants appeared to be as virulent for calves as the organisms from which they were derived. They could not be isolated from phage-lysed cultures of any of the six strains but mutants identical to the $E$. coli B41 and B85 ones were isolated from phage-lysed cultures of mixtures of the six strains. Because they were only isolated from these mixtures and from calves given mixtures of the six $E$. coli strains and their phages, it is conceivable that the mutants were erstwhile sensitive organisms of a strain that had acquired genetic material from organisms of the other five strains that had altered their susceptibility to phage attack; the presence of large amounts of phage and lysed organisms in the environment would facilitate this acquisition. Whatever the origin of these mutant bacteria, mutant phages that in a limited number of experiments prevented them or their parent organisms from causing disease in calves were isolated without difficulty from phages that were only active on their parents. It therefore seems possible that if such problems arose during the field use of phages they could be overcome.

The isolation from calves of the extraneous phage, designated $S 48 / 2$, under conditions that strongly suggested that it was suppressing the multiplication of $E$. coliS 48 , one of the strains with which they were infected, is reminiscent of the writings of D'Herelle (1930) who referred to epidemics being abruptly terminated by the entry into the environment of a phage active on the causal organism. In view of this and our other observations, it is conceivable that the therapy of bacterial disease might have taken a different course, a more successful one, if in the immediate years following the discovery of phages, a period of intense research activity stimulated by the absence of specific treatments for bacterial disease, more knowledge had been available on the aetiology and pathogenesis of bacterial disease. This would have made investigators aware of the diseases most likely to respond to phage therapy. Such diseases would include infections caused by $E$. coli and Vibrio cholerae, organisms which are not located in host cells invulnerable to phage attack. The basic need of developing a method of controlling bacterial diseases today is much less urgent because of the advent of antibiotics, vaccines and fluid replacement therapy. Nevertheless, our studies have revealed that phage therapy, being a biological method of control, has unique properties of potential prophylactic value. They suggest that a reappraisal of its usefulness in augmenting present methods of controlling some animal and human diseases, and also plant diseases, might be worthwhile. As far as E. coli diarrhoea in calves is concerned, our phages could probably be used with success to control field outbreaks caused by any of our seven $E$. coli strains. Whether they would have general application when used as a pool is another matter. For this to become a possibility, the pool would first have to be tested against a large number of freshly isolated calf enteropathogenic $E$. coli strains obtained from widely 
separated outbreaks of disease and then probably augmented by the inclusion of new phages active on strains found to be resistant to the pool. It is clear, though, that the specificity of our phages is a disadvantage to their general use. The disadvantage may be overcome by the future isolation of less specific phages, or by the production of such phages by the techniques of genetic engineering.

We are grateful to Mrs Teresa Berrill, Professor P. M. Biggs, Mr Geoffery Hart, Miss Margaret Lovell and Mrs Shirley Pilcher for assistance in a variety of ways. The expenses of this work were defrayed, in part, by a grant from the Wellcome Trust; we thank them.

\section{REFERENCES}

ASChAFFEnBURG, R. (1949). The nutritive value of colostrum for the calf. 3. Changes in the serum protein of the newborn calf following the ingestion of small quantities of the non-fatty fraction. British Journal of Nutrition 3, 200-204.

D'Herelle, F. (1930). The Bacteriophage and its Clinical Applications. London: Baillière, Tindal \& Cox.

MiLeS, A. A. \& MiSRA, S. S. (1938). The estimation of the bactericidal power of blood. Journal of Hygiene 38, 732-749.

SMITH, H. Williams (1948). Calcium-deficient media: their effect on phage action. Nature, London 161, 397.

Smith, H. Williams \& Halls, S. (1967a). Observations by the ligated intestinal segment and oral inoculation methods on Escherichia coli infections in pigs, calves, lambs and rabbits. Journal of Pathology and Bacteriology 93, 499-529.

Smith, H. Williams \& Halls, S. (1967b). Studies on Escherichia coli enterotoxin. Journal of Pathology and Bacteriology 93, 531-543.
Smith, H. Williams \& Huggins, M. B. (1982) Successful treatment of experimental Escherichia coli infection in mice using phage: its general superiority over antibiotics. Journal of General Microbiology 128, 307-318.

Smith, H. Williams \& Huggins, M. B. (1983). Effectiveness of phages in treating experimental Escherichia coli diarrhoea in calves, piglets and lambs. Journal of General Microbiology 129, 26592675.

Smith, H. Williams \& Jones, J. E. T. (1963). Observations on the alimentary tract and its bacterial flora in healthy and diseased pigs. Journal of Pathology and Bacteriology 86, 387-412.

Smith, H. Williams, Huggins, M. B. \& Shaw, K. M. (1987). Factors influencing the survival and multiplication of bacteriophages in calves and in their environment. Journal of General Microbiology 133, $1127-1135$. 